\title{
Modeling the Groundwater Quality in parts of Eastern Niger-Delta, Nigeria using Multivariate Statistical Techniques
}

\author{
Amadi A.N. ${ }^{1, *}$, Nwankwoala H.O. ${ }^{2}$, Jimoh M. O. ${ }^{1}$, Dan-Hassan M. A. ${ }^{3}$, Aminu Tukur ${ }^{4}$ \\ ${ }^{1}$ Department of Geology, Federal University of Technology, PMB 65, Minna \\ ${ }^{2}$ Department of Geology, University of Port Harcourt, P.M.B 5323, Choba, Port Harcourt, Nigeria \\ ${ }^{3}$ Rural Water Supply and Sanitation Department, FCT Water Board, Garki, Abuja \\ ${ }^{4}$ Katsina State Rural Water Supply and Sanitation Agency, Nigeria \\ *Corresponding author: geoama76@gmail.com
}

Received September 15, 2014; Revised October 15, 2014; Accepted October 28, 2014

\begin{abstract}
Groundwater pollution is one of the environmental problems facing many coastal regions such as Niger Delta as a result of high population, urbanization and industrialization. The quality of groundwater in the Eastern Niger-Delta, Nigeria was investigated in this study using multivariate geostatistical techniques. Hydrogeological investigations show that the aquifers in the area are largely unconfined sands with intercalations of gravels, clay and shale. These findings indicate that the aquifer in the area is porous, permeable and prolific. The observed wide ranges and high standard deviations and mean in the geochemical data are evidence that there are substantial differences in the quality/composition of the groundwater within the study area. Heavy metal enrichment index revealed 12 elements in the decreasing order of: $\mathrm{Fe}>\mathrm{Ni}>\mathrm{Cu}>\mathrm{Zn}>\mathrm{Mn}>\mathrm{Cd}>\mathrm{V}>\mathrm{Co}>\mathrm{Pb}>\mathrm{Cr}>\mathrm{As}>\mathrm{Hg}$. The study identified salt intrusion, high iron content, acid-rain, hydrocarbon pollution, use of agrochemicals, industrial effluents and poor sanitation as contributors to the soil and water deterioration in the area. Saltwater/freshwater interface occurs between $5 \mathrm{~m}$ to $185 \mathrm{~m}$ while iron-rich water is found between $20 \mathrm{~m}$ to $175 \mathrm{~m}$. The first two factors are natural phenomenon due to the proximity of the aquifer to the ocean and probably downward leaching of marcasite contained in the overlying lithology into the shallow water table while the last four factors are results of various anthropogenic activities domiciled in the area. Owing to the monumental and devastating effects of hydrocarbon pollution in the area, the need to eradicate gas flaring and minimize oil spills in the area was advocated. The geostatistical evaluation approach employed in this study gave rise to the development of groundwater vulnerability map of Eastern Niger Delta. Communities where their boreholes have been contaminated by hydrocarbon should stop using such wells and government should provide them with alternative source of water for drinking and domestic purposes.
\end{abstract}

Keywords: groundwater quality, modeling, multivariate geostatistical techniques, Eastern Niger Delta, Nigeria

Cite This Article: Amadi A.N., Nwankwoala H.O., Jimoh M. O., Dan-Hassan M. A., and Aminu Tukur, "Modeling the Groundwater Quality in parts of Eastern Niger-Delta, Nigeria using Multivariate Statistical Techniques.” American Journal of Water Resources, vol. 2, no. 5 (2014): 118-125. doi: 10.12691/ajwr-2-5-3.

\section{Introduction}

Eastern Niger Delta is the operational base of major oil producing and servicing companies in Nigeria. Petroleum exploration and exploitation have triggered adverse environmental impacts in the Delta area of Nigeria through incessant environmental, socio-economic and physical disasters that have accumulated over the years due to limited scrutiny and lack of assessment (Achi, 2003; Amadi et al., 2012a). In Nigeria, immense tracts of mangrove forests have been destroyed as a result of petroleum exploitation in the mangroves and these have not only caused degradation to the environment and destroyed the traditional livelihood of the region but have caused environmental pollution that has affected weather conditions, soil fertility, groundwater, surface water, aquatic and wildlife. If this trend is allowed to continue unabated, it is most likely that the food web complexes in this wetland might be at a higher risk of induced heavy metal contamination (Nikolaidis et al., 2008). This unhealthy situation continues to attract the interest of environmental observers and calls for evaluation of the impact of exploration and exploitation activities in the coastal areas of Nigeria and this is part of what this paper intends to address.

To meet the ever-increasing water demand in the region, groundwater is being extensively used to supplement the surface water thereby subjecting it to over-exploitation for domestic, agricultural, urban and industrial uses which results in the deterioration of groundwater in coastal areas (Macklin, et al., 2003). Increasing urbanization is taking 
place along the coastlines of the Niger Delta and causing increased use of groundwater and it has a large impact on the quality and quantity of groundwater system in the area. In many countries around the world, including Nigeria, groundwater supplies may have become contaminated through various human activities, which have impact on the health and economic status of the people. The discharge of untreated waste water, soakaway, pit-latrine as well as agricultural water runoff from farms can all lead to the deterioration and contamination of groundwater in coastal aquifers via infiltration through the overlying formation (Adams et al., 2008).

\subsection{Statement of the Problems}

The impact of hydrocarbon pollution in terms of gas flaring and oil spillage on the environment and health of host communities in Niger Delta, Nigeria is of great concern. The upsurge in human activities due to the presence of oil companies in the area and the propensity of contaminant infiltrating through the porous and permeable formation into the shallow groundwater table has necessitated the study, which intended to provide useful baseline information and geo-reference point on the degree of groundwater contamination in the area resulting from anthropogenic activities in the area.

\subsection{Aims of the Research}

The study seeks to provide baseline information on the suitability of groundwater in Eastern Niger Delta for domestic and other purposes using applied and multivariate geostatistical approach.

\subsection{Study Area Description}

The study area lies within the eastern Niger Delta region of Nigeria between latitude $4^{\circ} 40^{\mathrm{I}} \mathrm{N}$ and $5^{\circ} 40^{\mathrm{I}} \mathrm{N}$ and longitude $6^{\circ} 50^{\mathrm{I}} \mathrm{E}$ and $7^{\circ} 50^{\mathrm{I}} \mathrm{E}$ (Figure 1). It covers parts of Port-Harcourt, Aba and Owerri (Figure 1).

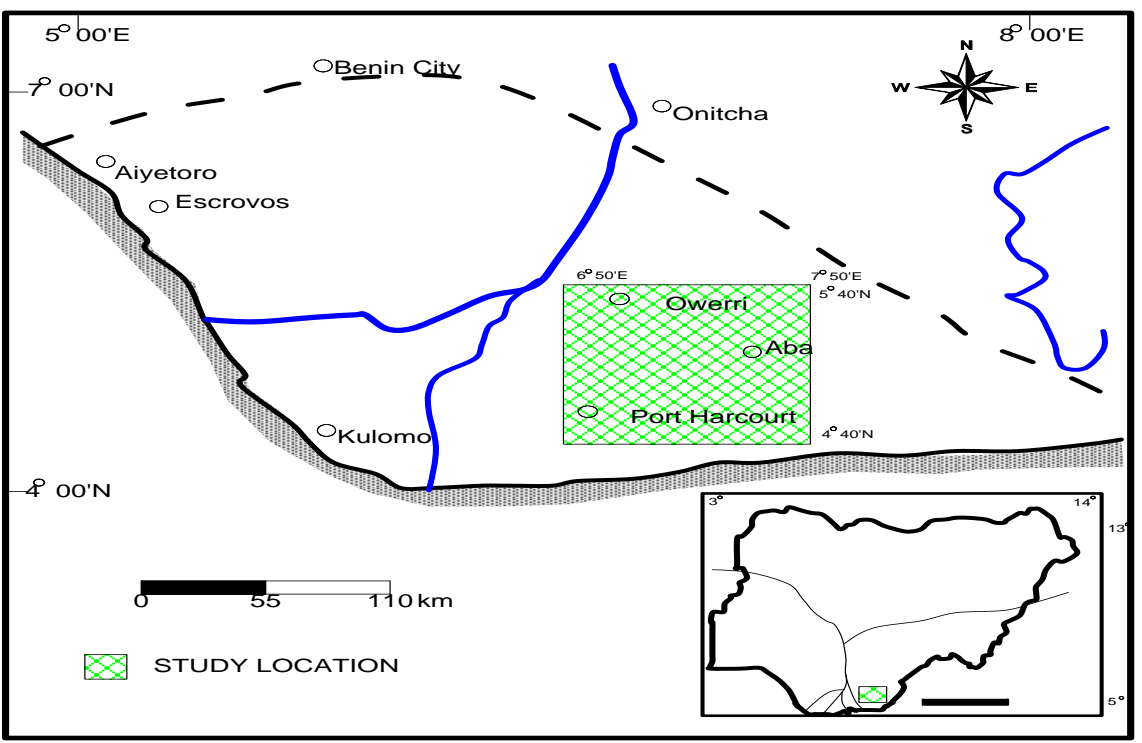

Figure 1. Map of Niger Delta showing the study area

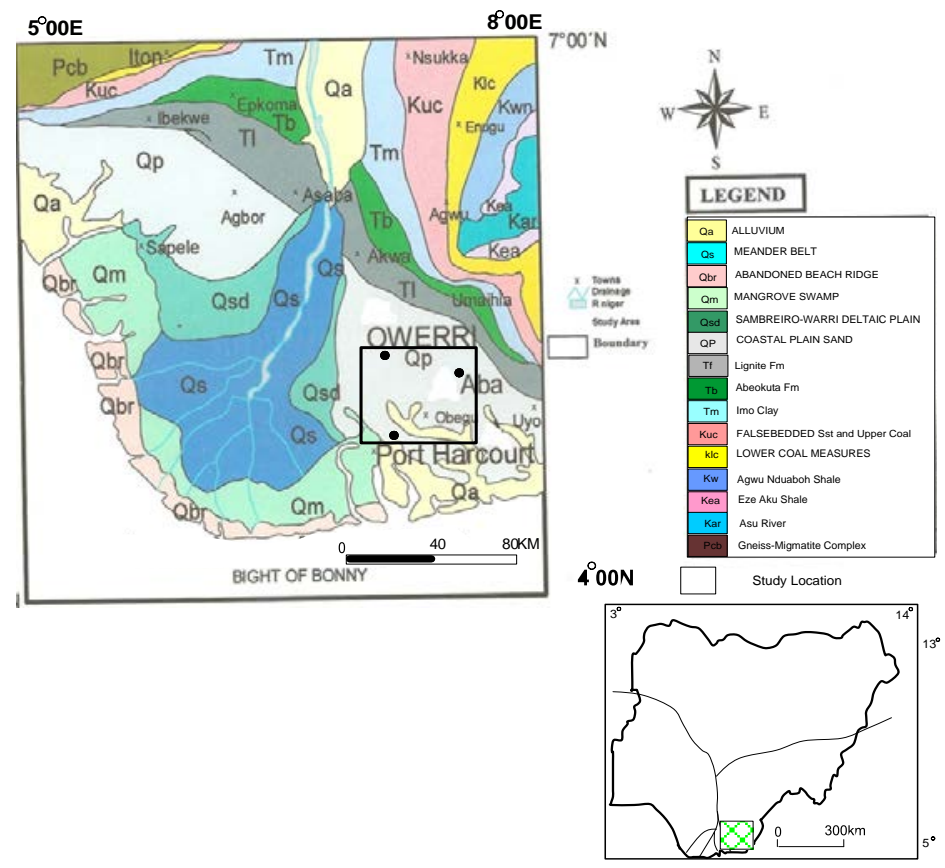

Figure 2. Geological map of Niger Delta, Nigeria (Modified from Weber and Daukoru, 1976) 


\subsection{Geology and Hydrogeology of the Area}

The study area (Port-Harcourt, Aba, Owerri and environs) is underlain by Pliocene-Pleistocene Benin Formation (Figure 2) belonging to the Coastal Plain-sand. The type locality of the formation is in Port-Harcourt, Aba and Owerri where the formation overlies the older Ogwashi-Asaba Formation (Ezeigbo and Aneke, 1993). The formation outcrops sometimes in both surface (outcrop) and subsurface in mode of occurrence.

\subsection{Fieldwork}

A total of 140 groundwater samples were collected between January, 2009 and November, 2011 using two sets of polyethylene bottles of one liter capacity, for cation and anion analysis and labeled accordingly. The boreholes were allowed to flow for about 2 minutes before the water is collected, and containers were thoroughly washed and rinsed with the water to be collected into them. Samples for the determination of cations were stabilized with a drop of dilute hydrochloric acid on collection. All the samples were preserved by refrigeration and analyzed within 24 hours of collection. The analyses were carried out in accordance with APHA (1998) standard. A variety of techniques including $x$-ray fluorescence (XRF), neutron activation analysis (NAA), inductively coupled plasmaatomic emission spectrometry (ICP-AES), atomic absorption spectrometry (AAS) and graphite furnace atomic absorption spectrometry (GFAAS) have been used for evaluating the heavy metal concentration. The physical parameters $\mathrm{pH}$ and conductivity were determined on the field using a calibrated $\mathrm{pH}$ meter and conductivity meter respectively. The microbial analysis was done using carried out using the filter membrane method and presumptive count and each sample was incubated for at least 24 hours

\subsection{Geostatistical Analysis}

The factor analysis (FA) and principal component analysis (PCA) have emerged as a useful tool for better understanding of the relationship among variables and for revealing groups (or clusters) that are mutually correlated within a data body. The correlation pattern between the different physical, chemical and bacteriological properties and the sampling sites were evaluated using factor/principal analysis. As could be seen in Table 1, factors explaining variance percentage lower than 6.08 percent have been rejected, aiming at interpreting the significance of the factors in an easier way. FA/PCA (raw matrix rotated) on the same standardized data were used with eigenvalues higher than one to generate six varifactors, accounting for 90.70 percent of the total variance.

Factor-1 has the highest loading of $29.16 \%$ and the contributors include conductivity, total dissolved solid (TDS), electrical conductivity (EC), chloride, calcium, magnesium, total hardness (TH), sodium and salinity. These factors can be associated with the seawater intrusion which leached into the aquifer system, increases the concentrations of these ions by its percolation and longer residence time. High tides and uncontrolled groundwater abstraction are the main factors that induce the infiltration of saltwater into the aquiferous zone.
Factor-2 explains $20.43 \%$ and includes $\mathrm{pH}$, silica, bicarbonate, chloride, iron, potassium, sulphate and total suspended solid (TSS). The TSS may be as a result of the partial dissolution of these ions (bicarbonate, chloride, iron, silica, potassium and sulphate) in the water either through natural means such as chemical weathering in the course of groundwater movement or anthropogenic interference and the processes are enhanced by a low $\mathrm{pH}$ condition. The iron content in the marcasite from the underlying shale and coal horizon of the Ogwashi-Asaba Formation is mobilized and leach into the shallow water table due to the porous and permeable nature of the aquiferous layer. Excessive iron in the body does not present any health hazard, only the turbidity, taste and appearance of the drinking water will usually be affected.

Factor-3 has a high loading for temperature, biochemical oxygen demand (BOD), chemical oxygen demand (COD), E.coli, phosphate, nitrate and total coliform (TC) and it accounts for $15.14 \%$ of the total variance (Table 2). These may be attributed to urban groundwater pollution arising from faecal contamination (E.coli and TC), fertilizer application (nitrate and phosphate), oil spillage (BOD and COD) and gas flaring (temperature). The rate of dissolution of BOD, COD, E.coli, TC, phosphate and nitrate are temperature dependent. The poor sanitary situation in the area is responsible for the high E.coli and total coliform content in the water, as majority of the pit-latrine and soakaway in the area are unlined and poorly sited. During pumping of the well, water is discharged and the recharging water may be accompanied by plume from the nearby toilet system.

Factor-4 accounts for $11.61 \%$ of the total variance (Table 2) with copper, fluoride, iron, manganese and zinc as the contributing factor. They are used in electroplating, alloys, roofing, cooking utensils, coins and paint manufacture. Their enrichment in the groundwater may be related to the various activities taking place in the area as well as decomposition and leaching of materials that contain these metals. It could also arise from the impacts of oil spills, gas flaring and decomposition of drilling wastes. Iron could also come from leaching of the thick lateritic overburden via chemical weathering.

Factor-5 has a moderate loading of $8.28 \%$ of the total variance (Table 1) and is attributed to cadmium, chromium, copper and nickel. These metals are raw material used in making alloys, batteries, electronics, plastics, glass and electrical wiring. When these products are damaged, they are discarded and during decomposition processes, these metals are leached away and they may finally come in contact with the aquifer system. They may also be attributed to oil spills and gas flaring activities taking place in the area as well as through indiscriminately dumped drilling wastes in the area.

Factor-6 has the lowest loading of $6.08 \%$ with arsenic, cobalt, lead and mercury. These metals are carcinogenic at low concentration (Aboud and Nandini, 2009) and their presence may be due to the discharge of industrial effluent from the industries domiciled in the area as well as gas flaring and oil spill activities in the area.

It is worthy of note that the masking (shielding) effect of chemically similar elements such as $\left(\mathrm{Na}^{+}+\mathrm{K}^{+}\right)$and $\left(\mathrm{HCO}_{3}{ }^{-}+\mathrm{CO}_{3}{ }^{-}\right)$as obtained in Piper diagram (Figure 3) and Durov diagram (Figure 4) has been avoided by the use of these geostatistical techniques such as principal 
component analysis, factor analysis, water quality index and metal pollution index applied in the present study. Furthermore, physical, bacteriological parameters and heavy metals parameters that are not used in hydrochemical facies classification as in Piper, Durov,
Stiff and Schoeller diagrams are now used in the geostatistical techniques thereby giving it a detailed, comprehensive and precise reflection of the concentration/contribution of each parameter in the groundwater pollution.

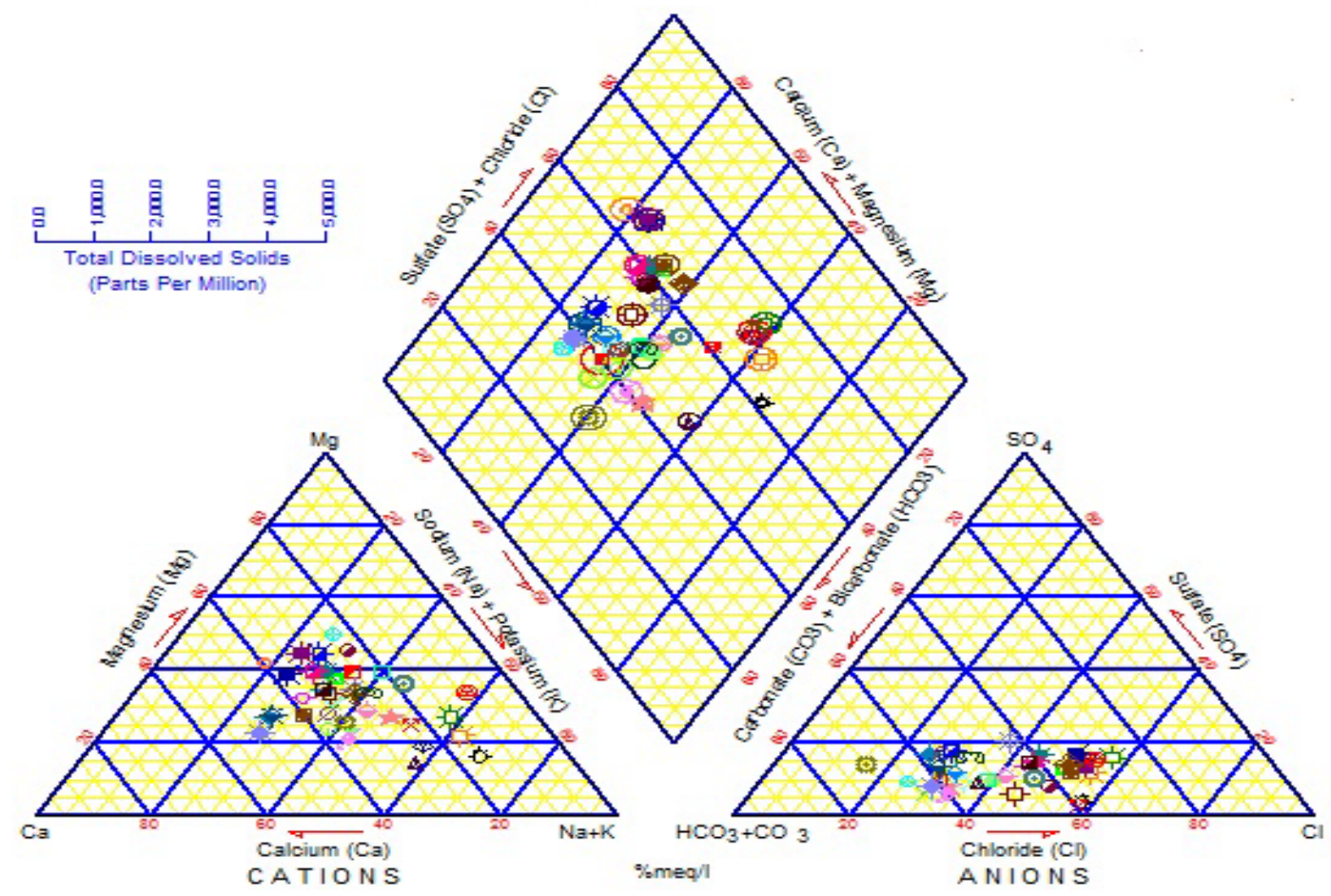

Figure 3. Piper diagram of Groundwater in the study area

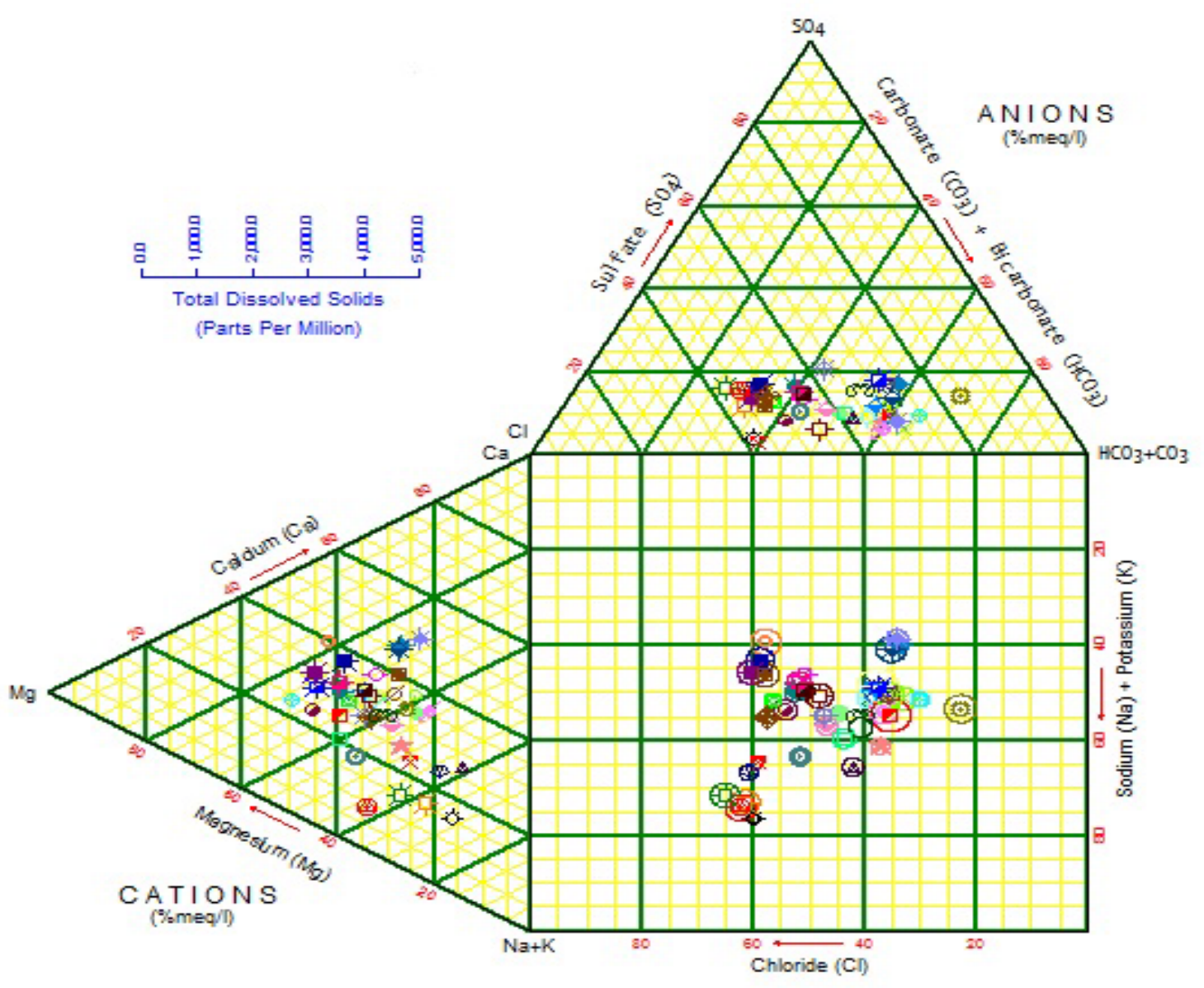

Figure 4. Durov diagram of Groundwater in the study area 
Table 1. Factor Analysis of Groundwater in the Coastal Plain-sand of Eastern Niger Delta

\begin{tabular}{|c|c|c|c|c|c|c|}
\hline Parameters & Factor 1 & Factor 2 & Factor 3 & Factor 4 & Factor 5 & Factor 6 \\
\hline Arsenic & 0.345 & 0.325 & 0.211 & 0.080 & 0.258 & 0.581 \\
\hline BOD & 0.123 & 0.234 & 0.680 & 0.406 & 0.321 & 0.231 \\
\hline Bicarbonate & 0.086 & 0.605 & 0.234 & 0.278 & 0.205 & 0.245 \\
\hline Cadmium & 0.231 & 0.121 & 0.023 & 0.298 & 0.623 & 0.329 \\
\hline Calcium & 0.789 & 0.458 & 0.219 & 0.308 & 0.067 & 0.244 \\
\hline Cobalt & 0.141 & 0.010 & 0.377 & 0.074 & 0.148 & 0.511 \\
\hline Chloride & 0.985 & 0.723 & 0.241 & 0.329 & 0.401 & 0.310 \\
\hline Chromium & 0.235 & 0.333 & 0.219 & 0.102 & 0.644 & 0.090 \\
\hline COD & 0.317 & 0.283 & 0.508 & 0.321 & 0.157 & 0.049 \\
\hline Copper & 0.215 & 0.104 & 0.210 & 0.765 & 0.593 & 0.301 \\
\hline E.Cond. $(\mu \mathrm{s} / \mathrm{cm})$ & 0.843 & 0.187 & 0.091 & 0.207 & 0.412 & 0.214 \\
\hline E.Coli (cfu/100ml) & 0.156 & 0.309 & 0.792 & 0.214 & 0.321 & 0.109 \\
\hline Fluoride & 0.200 & 0.098 & 0.190 & 0.526 & 0.239 & 0.198 \\
\hline T. Hardness & 0.890 & 0.120 & 0.234 & 0.245 & 0.234 & 0.206 \\
\hline Iron & 0.128 & 0.844 & 0.118 & 0.648 & 0.276 & 0.234 \\
\hline Lead & 0.321 & 0.232 & 0.380 & 0.124 & 0.178 & 0.598 \\
\hline Mercury & 0.139 & 0.081 & 0.212 & 0.005 & 0.080 & 0.506 \\
\hline Magnesium & 0.612 & 0.219 & 0.204 & 0.112 & 0.198 & 0.256 \\
\hline Manganese & 0.097 & 0.125 & 0.102 & 0.688 & 0.027 & 0.294 \\
\hline Nickel & 0.129 & 0.183 & 0.310 & 0.129 & 0.623 & 0.023 \\
\hline Nitrate & 0.218 & 0.390 & 0.588 & 0.213 & 0.069 & 0.216 \\
\hline $\mathrm{pH}$ & 0.393 & 0.768 & 0.342 & 0.147 & 0.216 & 0.143 \\
\hline Phosphate & 0.107 & 0.352 & 0.701 & 0.218 & 0.231 & 0.389 \\
\hline Potassium & 0.315 & 0.576 & 0.215 & 0.109 & 0.068 & 0.291 \\
\hline Salinity & 0.955 & 0.266 & 0.012 & 0.234 & 0.219 & 0.278 \\
\hline Silica & 0.236 & 0.762 & 0.324 & 0.250 & 0.135 & 0.289 \\
\hline Sodium & 0.928 & 0.215 & 0.248 & 0.235 & 0.089 & 0.215 \\
\hline Strontium & 0.263 & 0.233 & 0.213 & 0.290 & 0.045 & 0.503 \\
\hline Sulphate & 0.247 & 0.611 & 0.356 & 0.213 & 0.066 & 0.156 \\
\hline TDS & 0.861 & 0.257 & 0.120 & 0.276 & 0.045 & 0.207 \\
\hline Temp. $\left({ }^{\circ} \mathrm{C}\right)$ & 0.312 & 0.089 & 0.621 & 0.258 & 0.071 & 0.135 \\
\hline TSS & 0.234 & 0.619 & 0.126 & 0.223 & 0.009 & 0.087 \\
\hline T. Coliform (cfu/ml) & 0.109 & 0.103 & 0.625 & 0.412 & 0.224 & 0.231 \\
\hline Zinc & 0.387 & 0.312 & 0.023 & 0.634 & 0.129 & 0.079 \\
\hline Eigenvalue & 6.123 & 3.870 & 3.178 & 2.229 & 1.738 & 1.276 \\
\hline$\%$ of Variance & 29.16 & 20.43 & 15.14 & 11.61 & 8.28 & 6.08 \\
\hline Cumulative \% & 29.16 & 49.59 & 64.73 & 76.34 & 84.62 & 90.70 \\
\hline
\end{tabular}

BOD-biochemical oxygen demand; COD-chemical oxygen demand; TC-total coliform;

E.Cond-Electrical Conductivity; EC-Escherichia coli; TSS-total suspended solid

\subsection{Water Quality Index}

The computed WQI Values for the study area is contained in Table 2 while the overall water quality index (WQI) was calculated by aggregating the quality rating $\left(\mathrm{q}_{\mathrm{i}}\right)$ with unit weight $\left(\mathrm{w}_{\mathrm{i}}\right)$ linearly and the result shown in Table 3.

$$
\text { Overall WQI }=\frac{\sum q w i}{\sum w i}=\frac{460442.528}{1614.45}=285.20
$$

The high value of WQI obtained may be as a result of the high concentration of salinity, TDS, TH, EC, COD, nitrate, copper, iron, nickel, zinc, lead, chromium and coliform bacteria in the groundwater which can be attributed to natural sources through saltwater intrusion and chemical weathering processes as well as anthropogenic sources through the various human activities such as oil spill, gas flaring and indiscriminate dumping of waste in the area. The study has revealed that about $25 \%$ of the groundwater system in the area is good for drinking and domestic purposes. Salt intrusion and hydrocarbon pollution were identified as the major groundwater contaminants. This implies that groundwater deterioration in the area has both natural and anthropogenic signatures.

\subsection{Metal Pollution Index}

Metal pollution index (MPI) is a method of rating that shows the composite influence of individual parameters on the overall quality of water (Amadi, 2011). The rating is a value between zero and one, reflecting the relative importance individual quality considerations. The higher the concentration of a metal compared to its maximum allowable concentration, the worse the quality of the water (Table 4) while the calculated water quality classification using MPI value is contained in Table 5. It uses elemental composition in groundwater in the classification (Tamasi and Cini, 2004; Amadi, 2012; Amadi et al., 2013; Amadi et al, 2014). The MPI is calculated using the equation below:

$$
M P I=C i / M A C i
$$

Where $\mathrm{Ci}$ is metal concentration in the water sample 
MACi is the maximum allowable concentration of the metal

Metals are metallic elements that have a relatively high density and are toxic at very low concentration. It refers to chemical elements with a specific gravity that is at least 5 times the specific gravity of water. The fact that heavy metal bioaccumulate in human organs and are poisonous at low concentration makes it an important water quality parameter in evaluating its suitability.

Table 2. Computed WQI Values for the Study Area

\begin{tabular}{|c|c|c|c|c|c|}
\hline Parameters (mg/l) & $\mathrm{C}_{\mathrm{i}}$ & $\mathrm{S}_{\mathrm{i}}$ & $\mathrm{q}_{\mathrm{i}}$ & $\mathrm{W}_{\mathrm{i}}$ & $\mathrm{q}_{\mathrm{i}} \mathrm{W}_{\mathrm{i}}$ \\
\hline Arsenic & 0.007 & 0.010 & 70.000 & 100.000 & 7000.000 \\
\hline BOD & 5.600 & 6.000 & 93.333 & 0.167 & 15.587 \\
\hline Calcium & 46.530 & 200.000 & 3.265 & 0.005 & 0.016 \\
\hline Chloride & 175.200 & 250.000 & 64.480 & 0.004 & 0.258 \\
\hline Chromium & 0.070 & 0.050 & 140.000 & 20.000 & 2800.000 \\
\hline Copper & 0.080 & 1.000 & 8.000 & 1.000 & 8.000 \\
\hline Conductivity( $\mu \mathrm{s} / \mathrm{cm})$ & 254.000 & 1000.000 & 25.138 & 0.001 & 0.025 \\
\hline COD & 10.600 & 10.000 & 106.00 & 0.100 & 10.600 \\
\hline E.Coli (cfu/100ml) & 22.000 & 0.000 & 0.000 & 0.000 & 0.000 \\
\hline Fluoride & 0.850 & 1.500 & 56.667 & 0.667 & 37.797 \\
\hline Total Hardness & 54.310 & 200.000 & 17.155 & 0.005 & 0.086 \\
\hline Iron & 0.620 & 0.300 & 18.600 & 3.333 & 61.994 \\
\hline Lead & 0.080 & 0.010 & 800.000 & 100.000 & 80000.000 \\
\hline Magnesium & 33.160 & 150.000 & 2.107 & 0.007 & 0.015 \\
\hline Manganese & 0.190 & 0.200 & 95.000 & 5.000 & 475.000 \\
\hline Mercury & 0.003 & 0.001 & 300.000 & 1000.000 & 300000.000 \\
\hline Nickel & 0.280 & 0.020 & 1400.000 & 50.000 & 70000.000 \\
\hline Nitrate & 17.820 & 50.000 & 25.540 & 0.020 & 0.511 \\
\hline $\mathrm{pH}$ & 5.460 & $6.500-8.500$ & 82.267 & 0.133 & 10.942 \\
\hline Phosphate & 10.290 & 5.000 & 5.800 & 0.200 & 1.160 \\
\hline Potassium & 20.470 & 100.000 & 0.470 & 0.010 & 0.005 \\
\hline Sodium & 61.590 & 200.000 & 0.795 & 0.005 & 0.004 \\
\hline Sulphate & 98.620 & 100.000 & 69.980 & 0.010 & 0.699 \\
\hline TDS & 155.000 & 500.000 & 29.098 & 0.002 & 0.058 \\
\hline T. Coli (cfu/ml) & 15.000 & 10.000 & 120.000 & 0.100 & 12.000 \\
\hline TSS & 14.600 & 500.000 & 0.926 & 0.002 & 0.002 \\
\hline Zinc & 0.700 & 3.000 & 23.333 & 0.333 & 7.769 \\
\hline
\end{tabular}

BOD-biochemical oxygen demand; COD-chemical oxygen demand;

TC-total coliform; EC-Escherichia coli; TSS-total suspended solid

Table 3. Groundwater Quality Classification Based on WQI Value

\begin{tabular}{|c|c|c|}
\hline WQI value & Water quality & Water samples (\%) \\
\hline$<50$ & Excellent & 09 \\
\hline $50-100$ & Good water & 16 \\
\hline $100-200$ & Poor water & 24 \\
\hline $200-300$ & Very poor water & 31 \\
\hline$>300$ & Unsuitable for drinking & 20 \\
\hline
\end{tabular}

Table 4. Calculated Metal Pollution Index for the Groundwater in the Area

\begin{tabular}{ccc|}
\hline Parameters (mg/l) & $C_{i}$ & $M A C_{i}$ \\
\hline Arsenic & 0.007 & 0.01 \\
Cadmium & 0.11 & 0.02 \\
Cobalt & 0.02 & 0.01 \\
Chromium & 0.07 & 0.05 \\
Copper & 0.8 & 1.00 \\
Iron & 0.62 & 0.30 \\
Lead & 0.08 & 0.01 \\
Manganese & 0.19 & 0.20 \\
Mercury & 0.003 & 0.001 \\
Nickel & 0.28 & 0.02 \\
Zinc & 0.17 & 3.00 \\
\hline & & \\
\hline Table 5. Water Quality Classification Based on MPI Value \\
\hline MPI Reference Value & MPI Quality Rating & Percentage \\
\hline$<0.01$ & Very lightly polluted & 00.0 \\
\hline $0.01-1.0$ & Lightly polluted & 02.0 \\
\hline $1.0-5.0$ & Moderately polluted & 55.0 \\
\hline $5.0-10.0$ & Highly polluted & 18.0 \\
\hline$>10.0$ & Very highly polluted & 09.0 \\
\hline
\end{tabular}

\subsection{Groundwater Vulnerability Map for the Study Area}

The knowledge of the geology and hydrogeology of the area, coupled with the information obtained through geophysical survey, borehole logging, sieve analysis,

$\begin{array}{cc}\text { MPI Value } & \text { Rating } \\ 0.70 & \text { Lightly polluted } \\ 5.50 & \text { Highly polluted } \\ 2.00 & \text { Moderately polluted } \\ 1.40 & \text { Moderately polluted } \\ 1.90 & \text { Moderately polluted } \\ 2.10 & \text { Moderately polluted } \\ 8.00 & \text { Highly polluted } \\ 0.95 & \text { Lightly polluted } \\ 3.00 & \text { Moderately polluted } \\ 14.00 & \text { Very highly polluted } \\ 1.57 & \text { Moderately polluted }\end{array}$

permeability test, pumping test and laboratory analysis, employed in this study were used to develop the vulnerability map for the aquifer system in the area (Figure 5). The entire area was categorized into three region based on pollutant dominance: areas of high vulnerability, moderate vulnerability and low vulnerability. The high vulnerability area are domiciled by high profile anthropogenic activities and have witnessed long term environmental degradation arising from gas flaring, oil spills, open dumpsites, urbanization and industrialization. The local geology of the southern portion might be also a contributing factor. The low vulnerability area is dominated by farming and industrial activities are quite 
minimal. The medium/moderate vulnerability region shares the characteristics of both high and low vulnerability region.

The use of multivariate geostatistical techniques in evaluating groundwater quality has been successfully demonstrated in this study. The geochemical signature obtained from factor analysis, principal component analysis, water quality index and metal pollution index were used in the generation of groundwater vulnerability map for Eastern Niger Delta. The revelations in terms of water quality obtained in the synergy from multivariate statistical approach used in this study are efficient and commendable.

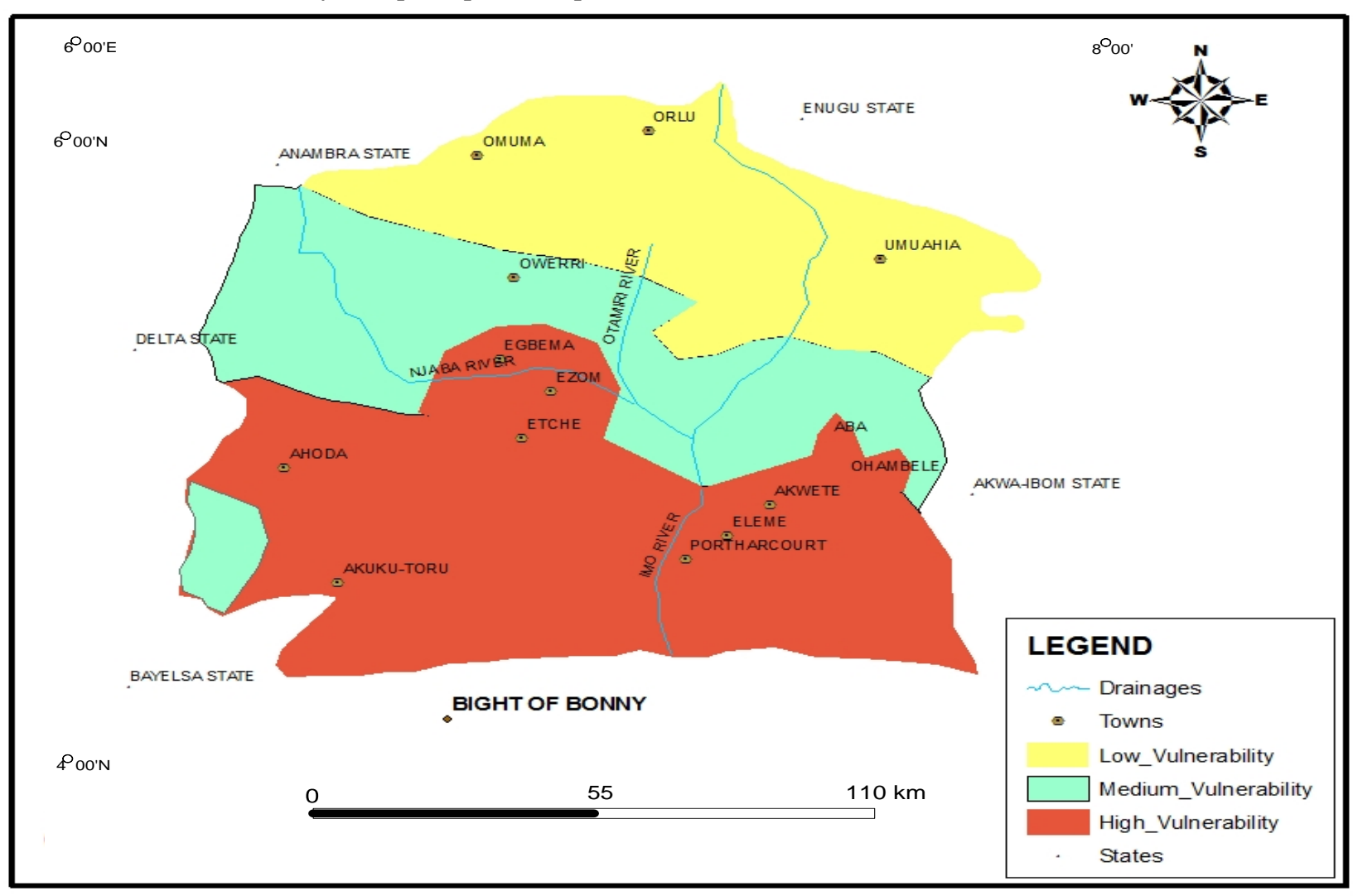

Figure 5. Groundwater Vulnerability Map of Eastern Niger Delta

\section{Conclusion and Recommendation}

This study has clearly established that hydrocarbon pollution constitute a major source of soil and water pollution in the oil producing region of Eastern Niger Delta, Nigeria. The metal concentration decreases in the order of: $\mathrm{Fe}>\mathrm{Ni}>\mathrm{Cu}>\mathrm{Zn}>\mathrm{Mn}>\mathrm{Cd}>\mathrm{V}>\mathrm{Co}>\mathrm{Pb}>$ $\mathrm{Cr}>\mathrm{As}>\mathrm{Hg}$. The soil $\mathrm{pH}$ is generally low, signifying acidic soil while loamy soil characterize the top soil in the area and these condition enhances the mobility and bioaccumulation of heavy metals in groundwater. The study has revealed that the various anthropogenic activities domiciled in the area have constituted serious water quality problems which have resulted to classic environmental and health challenges in their host communities.

Salinity and high iron content constitutes the major natural sources of groundwater pollution in the area. Many boreholes in the area have been abandoned solely due to the problem of salt water intrusion and or high iron content. The impact of salt intrusion and hydrocarbon contamination are more on the southern part of the area while the high iron content is more on the northern sector. The dis-use of contaminated water well by the communities and the provision of alternative sources for drinking and domestic purposes were advocated.

\section{Reference}

[1] Aboud, S. J. \& Nandini, N., (2009). Heavy metal analysis and sediment quality values in urban lakes. American Journal of Environmental Science, 5 (6), 678-687.

[2] Achi, C., (2003). Hydrocarbon Exploitation, Environmental degradation and Poverty: The Niger Delta experience. In proceedings of the Environmental Pollution Conference, Dublin, 78-94.

[3] Adams, R. H., Guzmán-Osorio, F. J., \& Zavala, C. J. (2008). Water repellency in oil contaminated sandy and clayey soils. International Journal of Environmental Science and Technology, 5 (4), 445-454.

[4] Amadi, A. N., (2011). Quality Assessment of Aba River using Heavy Metal Pollution Index. American Journal of Environmental Engineering, (1) 1-5.

[5] Amadi, A. N., (2012). Quality Assessment of Aba River using Heavy Metal Pollution Index. American Journal of Environmental Engineering, 2 (1), 45-49

[6] Amadi, A. N., Olasehinde, P. I., Yisa, J., Okosun, E. A., Nwankwoala, H. O. and Alkali, Y. B., (2012). Geostatistical assessment of groundwater quality from coastal aquifers of Eastern Niger Delta, Nigeria. Geosciences, 2 (3), 51-59.

[7] Amadi A. N., Dan-Hassan M. A., Okoye N. O., Ejiofor I. C. and Aminu Tukur, (2013). Studies on Pollution Hazards of Shallow Hand-Dug Wells in Erena and Environs, North-Central Nigeria. Environment and Natural Resources Research, 3 (2), 69-77.

[8] Amadi, A. N., Olasehinde, P. I., Dan-Hassan, M. A, Okoye, N. O. and Ezeagu, G. G., (2014). Hydrochemical Facies Classification and Groundwater Quality Studies in Eastern Niger Delta, Nigeria. 
International Journal of Engineering Research and Development, 10 (3), 01-09.

[9] APHA, (1998). Standards methods for the examination of wate and wastewater. $19^{\text {th }}$ Edition American Water Works Association, Washington DC.

[10] Ezeigbo, H. I. and Aneke, B. C., (1993). Water Resources Development plan for Benin City and environs. Journ. Mining Geology, 29 (2), 147-159.

[11] Macklin, M. G., Brewer, P. A., Balteanu, D., Coulthard, T. J., Driga, B., Howard, A. J \& Zaharia, S., (2003). The long term fate and environmental significance of contaminant metals released by the January and March 2000 mining tailings dam failure in
Maramures County, upper Tisa basin, Romania. Applied Geochemistry, 18 (2), 241-257.

[12] Nikolaidis, C., Mandalos P. \& Vantarakis, A., (2008). Impact of intensive agricultural practices on drinking water quality in the EVROS Region (NE GREECE) by GIS analysis. Environmental Monitoring and Assessment. 143 (1-3), 43-50.

[13] Tamasi, G. \& Cini, R., (2004). Heavy metals in drinking waters from Mount Amiata. Possible risks from arsenic for public health in the province of Siena. Science of the Total Environment, 327, 41-51.

[14] Weber, K. J., \& Dankoru. E. M. (1975). Petroleum geology of Niger Delta, Tokyo, $9^{\text {th }}$ World Petroleum Congress Proceedings, London Applied Publishers, Ltd., 2, 209-221. 